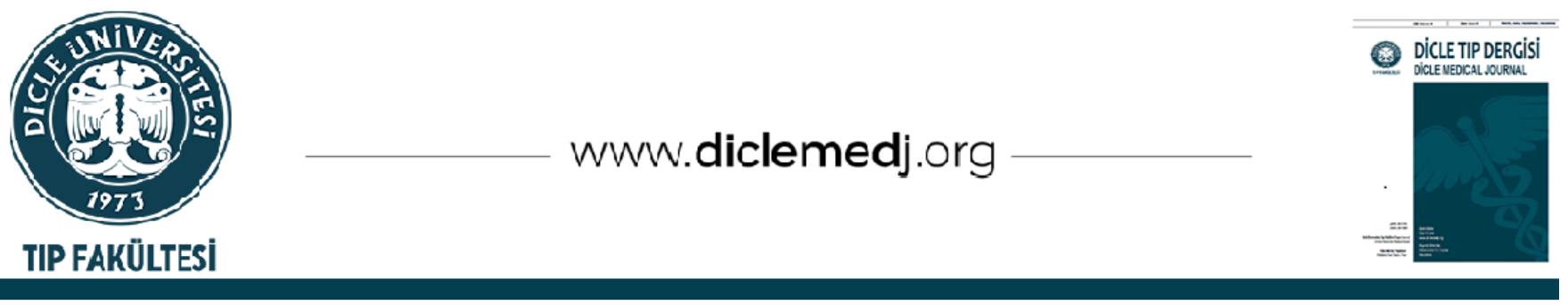

Original Article / Özgün Araştırma

\title{
The effect of ultrasound-guided suction curettage on reproductive outcomes in patients with cesarean scar pregnancy
}

\author{
Seyhun Sucu ${ }^{1}$, Çağdaş Demiroğlu ${ }^{2}$, Özge Kömürcü Karuserci ${ }^{i}{ }_{1}$, Hanifi Bademkiran ${ }^{1}{ }_{1}$ Emin \\ Sevinçler ${ }^{D}$, Hüseyin Çağlayan Özcan ${ }^{1}$ \\ 1 Gaziantep University, School of Medicine, Department of Obstetrics and Gynecology, Gaziantep, Turkey
}

2 Department of Gynaecology and Obstetrics, Faculty of Medicine, SANKO University, Gaziantep, Turkey

Received: 22.11.2020; Revised: 19.04.2021; Accepted: 27.04.2021

\begin{abstract}
Objective: This study aims to evaluate reproductive and pregnancy outcomes in patients with cesarean scar pregnancies (CSP) treated by suction curettage.

Methods: This retrospective observational study included 85 patients with CSP treated by suction curettage in a university hospital between 2013-2017. Reproductive status of the patients who could be reached by phone was inquired at 6-month intervals for three years.

Results: Hospital records and telephone follow-up data of the 44 patients who completed follow-up were analyzed. Nineteen patients did not desire pregnancy, while 25 patients reported wishing to conceive again. Twenty-three of these patients $(92 \%, 23 / 25)$ conceived spontaneously, 2 of them $(8 \%, 2 / 25)$ unable to conceive due to unexplained secondary infertility. Mean length of time from CSP to subsequent pregnancy was 12.3 months (range 2-36 months). Of these pregnancies, $11(47.8 \%, 11 / 23)$ resulted in birth without any obstetrical problems. Six patients $(26 \%, 6 / 23)$ experienced miscarriage, and three patients $(13 \%, 3 / 23)$ recurrent cesarean scar pregnancies. Two patients $(8.6 \%, 2 / 23)$ had abnormal placental invasion and one patient $(4.3 \%, 1 / 23)$ tubal ectopic pregnancy. The live birth rate among the pregnancies was $52.1 \%(12 / 23)$.
\end{abstract}

Conclusion: There is no consensus on the primary treatment regarding the reproductive outcomes. Suction curettage is a successful, reliable, inexpensive and easily applicable treatment when appropriate patients are selected. Furthermore, it has a minimal negative effect on fertility, so it can be considered as a first-line treatment option in patients who wish to have children in the future.

Keywords: Cesarean scar pregnancy; fertility outcomes; pregnancy outcomes; suction curettage

DOI: 10.5798/dicletip.944332

Correspondence / Yazışma Adresi: Seyhun Sucu, Gaziantep University, School of Medicine, Department of Obstetrics and Gynecology, Gaziantep, Turkey e-mail; sucuseyhun@gmail.com 


\section{Sezaryen skar gebeliğinde aspirasyon küretajın üreme sonuçları üzerine etkisi}

Öz

Amaç: Bu çalışma, aspirasyon küretaj yöntemi ile tedavi edilen sezaryen skar gebeliklerinde üreme ve gebelik sonuçlarını değerlendirmeyi amaçlamaktadır.

Yöntemler: Bu geriye dönük gözlemsel çalışmaya 2013-2017 yılları arasında Gaziantep Üniversite Hastanesinde sezaryen skar gebeliği nedeniyle aspirasyon küretaj yöntemi ile tedavi edilen 85 hasta dahil edildi. Hastaların üreme durumları 3 yıl boyunca, altı aylık periyodlarla telefonla aranarak sorgulandı.

Bulgular: Takibi tamamlanan 44 hastanın hastane kayıtları ve telefon takip verileri incelendi. On dokuz hasta gebelik istemediğini belirtirken, 25 hasta tekrar gebe kalmak istediğini bildirdi. Bu hastaların 23'ü $(\% 92,23 / 25)$ kendiliğinden gebe kaldı, 2' si $(\% 8,2 / 25)$ açıklanamayan sekonder infertilite nedeniyle gebe kalamadı. Sezaryen skar gebeliği tedavisinden sonra tekrar gebe kalıncaya kadar geçen ortalama süre 12.3 aydı (dağılım 2-36 ay). Bu gebeliklerden 11' i $(\% 47,8,11 / 23)$ herhangi bir obstetrik problem olmaksızın doğumla sonuçlandı. Altı hastanın gebeliği $(\% 26,6 / 23)$ düşükle, üç hastanın gebeliği $(\% 13,3 / 23)$ tekrarlayan sezaryen skar gebeliği ile sonuçlandı. İki hastada $(\% 8.6,2 / 23)$ anormal plasental invazyon ve bir hastada $(\% 4.3,1 / 23)$ tubal ektopik gebelik gözlendi. Gebelikler arasında canlı doğum oranı \%52.1 (12/23) idi.

Sonuç: Sezaryen skar gebeliklerinin yönetiminde üreme sonuçları açısından birincil tedavi yöntemi konusunda fikir birliği yoktur. Aspirasyon küretaj uygun hastalarda başarılı, güvenilir, ucuz ve kolay uygulanabilir bir tedavi yöntemidir. Ayrıca doğurganlık üzerine minimum olumsuz etkiye sahip olması nedeniyle, gelecekte çocuk sahibi olmak isteyen hastalarda birinci basamak tedavi seçeneği olarak düşünülebilir.

Anahtar kelimeler: Sezaryen skar gebeliği; doğurganlık sonuçları; gebelik sonuçları; aspirasyon küretaj.

\section{INTRODUCTION}

Cesarean scar pregnancy (CSP) is a rare form of ectopic pregnancy, which involves implantation within the scar from a previous cesarean delivery ${ }^{1}$. The incidence of CSP increased due to the recent rise in the rate of cesarean delivery and the broader use of ultrasound in the early stages of pregnancy $(1: 1899-1: 2226)^{2}$. Some etiological factors lead to CSP, including; placental pathologies, a history of ectopic pregnancy, and assisted reproductive technologies ${ }^{3}$. There is no consensus on the optimal management of CSP; however, all treatment modalities have the common objectives, including; preserving the uterus, minimizing complication rates, and being easily applicable ${ }^{4}$. Lower uterine segment resection, hysteroscopy, dilation \& curettage, systemic or local methotrexate, local potassium chloride $(\mathrm{KCl})$, uterine artery embolization and highintensity ultrasound can be used to preserve the uterus ${ }^{5}$.
Many previous studies suggested suction curettage combined with medical therapy as the first-line treatment. However, studies on the use of suction-curettage as a stand-alone treatment are quite scarce ${ }^{6,7}$. Performing stand-alone suction-curettage as conservative treatment is a simple and inexpensive method that does not have a potential of inducing systemic side effects.

Although successful pregnancy outcomes have been reported after various surgical treatment types, there are few studies regarding long-term fertility outcomes in patients with CSP in the literature ${ }^{8}$. This study aims to investigate the long-term post-treatment reproductive and pregnancy outcomes of patients with CSP who were treated by suction curettage alone.

\section{METHODS}

This retrospective observational study included 85 patients with CSP treated by suction 
curettage in a University hospital between 2013-2017. A flowchart related to these patients presented in Figure 1. Reproductive status of the patients who could be reached by phone was inquired at 6-month intervals for three years-patient follow-up completed in January 2020. The local ethics committee of Gaziantep University has approved this study (project number 2019/183).

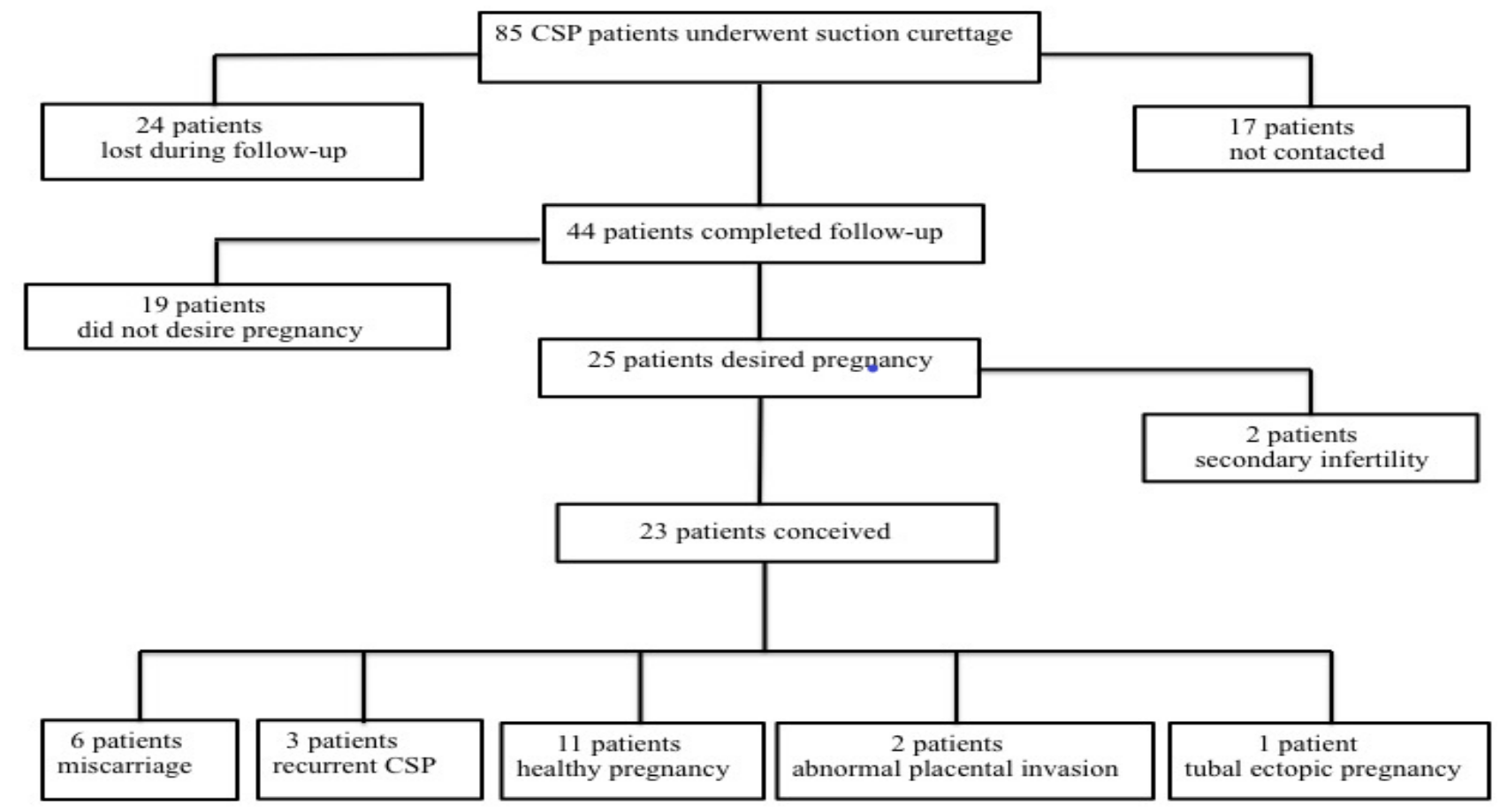

Figure 1. Flow chart

Same clinicians diagnosed all the patients by using transvaginal ultrasound (A GE VolusonTM S10). Our study's ultrasound inclusive diagnostic criteria were as follows: (Figure 2) $)^{9,10}$.

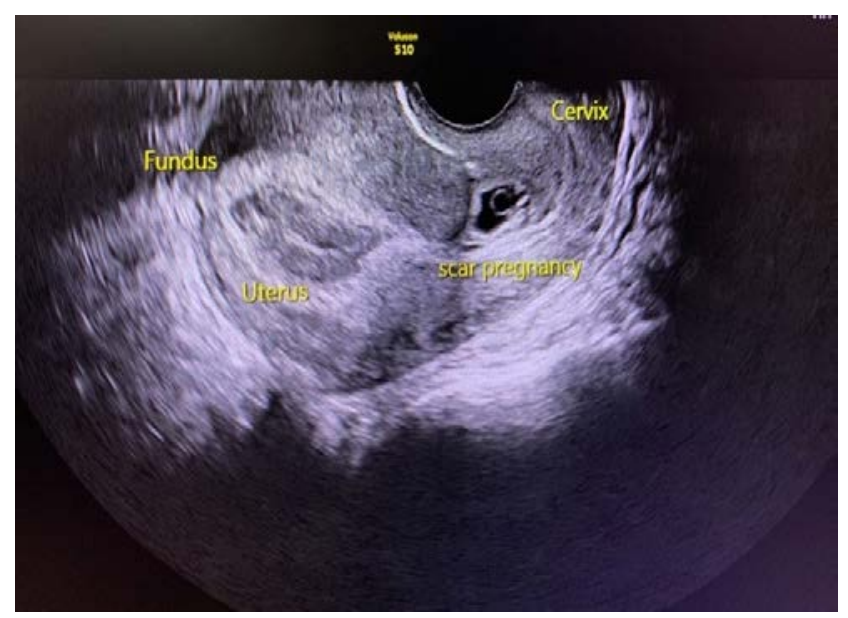

Figure 2. Transvaginal Ultrasound image of CSP
1. An empty uterine cavity and cervical canal

2. Gestational sac in the isthmic portion of the anterior uterine wall

3. Discontinuity in the anterior wall of the uterus on a sagittal plane of the uterus running through the amniotic sac

4. Loss of normal myometrium between the gestational sac and the bladder

5. Low-impedance high velocity peritrophoblastic vascular flow around the gestational sac on Doppler

The gestational week was determined according to the last menstrual period date in patients with regular menstrual cycles or evaluation crown-rump length or gestational sac in transvaginal ultrasound. Those with a pregnancy of 9 weeks or smaller were included 
in the study, and $\beta$-hCG was not used as a selection criterion.

All patients operated under mask anaesthesia in the dorsal lithotomy position. Suction curettage was performed by transabdominal ultrasound (TAUS) guidance, using a 6-8 mm Karman cannulas. After the cervix dilated, the Karman cannulas carefully inserted and full vacuum applied for 60 cc manual syringe (610-660 $\mathrm{mm} / \mathrm{Hg}$ ). The cannula's diameter was chosen as 1-2 mm smaller or equal to the gestational age determined according to the last menstrual period date. Patients could be followed-up by phone for three years, diagnosed before the 9th gestational week, had a residual myometrial scar thickness $\geq 3 \mathrm{~mm}$ on ultrasound, were not suspected of having vascular invasion on Doppler ultrasound and treated by only suction curettage were included in the study. The exclusion criteria were: those who did not meet the above-mentioned inclusion criteria, had suspected rupture, request for caesarean scar repair simultaneously, and were hemodynamically unstable. In our clinic, suction curettage or laparotomy is applied to the CSP patients, other treatment methods such as hysteroscopy, laparoscopy, methotrexate (MTX) treatment and uterine artery embolization are not performed.

Patients', histories, sociodemographic characteristics and complications were examined from the hospital records, and their reproductive and pregnancy status was questioned directly by phone.

The questions asked to the patients in phone interviews were as follows:

1- Did you wish to have children again after the curettage procedure? If so, were you able to conceive?
2- How long after the curettage procedure were you able to conceive?

3- Did your pregnancy result in a live birth, miscarriage, or another ectopic scar pregnancy?

4- What was the week of live birth or miscarriage?

5- Did you have abnormal placental invasion during your pregnancy?

6- Did you encounter any problems during the pregnancy?

The demographic data obtained in this study were analyzed using the SPSS (Version 23.0) program.

\section{RESULTS}

This study included 44 patients treated by suction curettage due to CSP and completed a 3year follow-up period (Figure 1). Of these patients, 41\% (18/44) were asymptomatic and diagnosed in their routine first-trimester examination. The most widespread complaint among symptomatic patients was vaginal bleeding, with a rate of $45.5 \%(20 / 44)$, followed by abdominal pain, with a rate of $36.4 \%$ $(16 / 44)$. In the ultrasonographic evaluation of 44 patients who underwent suction curettage with CSP diagnosis, only gestational sac in 27, embryos without a heartbeat in 11 and embryos with a heartbeat in 6 patients was observed. Demographic data of the patients with CSP who underwent suction curettage summarized in Table 1. Between 2013 and 2017, 119737 pregnant women evaluated in our clinic, and 85 were diagnosed with CSP. The incidence of CSP in our clinic during the study period is approximately $1 / 1408$. 
Table I: Demographic data of patients who underwent suction curettage for CSP

\begin{tabular}{|c|c|c|c|}
\hline Variables & Mean \pm Std. Dev. & Minimum & Maximum \\
\hline Age (year) & $32.04 \pm 4.77$ & 21 & 42 \\
\hline Gravidity (n) & $4.34 \pm 1.84$ & 2 & 9 \\
\hline Parity (n) & $2.39 \pm 0.95$ & 1 & 5 \\
\hline $\begin{array}{c}\text { Number of } \\
\text { living } \\
\text { children (n) }\end{array}$ & $2.29 \pm 0.82$ & 1 & 4 \\
\hline $\begin{array}{c}\text { History of } \\
\text { previous CS } \\
\text { (n) }\end{array}$ & $2.09 \pm 0.85$ & 1 & 4 \\
\hline $\begin{array}{c}\text { Gestational } \\
\text { Age (days) }\end{array}$ & $46.89 \pm 6.45$ & 2 & 36 \\
\hline $\begin{array}{c}\text { Time from } \\
\text { treatment to } \\
\text { conception } \\
\text { (months) }\end{array}$ & $12.30 \pm 8.34$ & & 63 \\
\hline \begin{tabular}{c} 
(monthe \\
\hline
\end{tabular}
\end{tabular}

In our interviews with the 44 patients: 19 patients $(43.2 \%, 19 / 44)$ did not desire another pregnancy while 25 patients $(56.8 \%, 25 / 44)$ desired pregnancy. Reproductive outcomes of the patients who planned pregnancy demonstrated in detail in Table 2. While fetal cardiac activity was detected in 14 (61\%) of 23 patients who conceived after CSP treatment, was not detected in 9 (39\%) of them. Heartbeat observed in only one of recurrent cesarean scar pregnancies (rCSP). Twelve pregnancies (52.1\%) resulted in a live birth; all of these underwent cesarean delivery in the 36th - 38th gestational week. There were two patients with abnormal placental invasion. One of them underwent hysterotomy due to vaginal bleeding in the 17th week, and the other had a cesarean hysterectomy due to intraoperative bleeding at the 36th week. Treatment methods performed in patients with being pregnant after CSP presented in Table 3. In the present study, the suction curettage success rate for CSP treatment was $97,7 \%$. Complications encountered during the suction curettage were uterine rupture and persistent bleeding. There were five complicated patients (11.3\%) associated with suction curettage. One of these complications was uterine rupture $(2.3 \%)$, and 4 (9\%) were vaginal bleeding that did not respond to uterotonics. Uterine rupture was repaired with a double-layer closure by the mini-laparotomy route. Balloon tamponade was performed successfully by inflating 22 F Foley catheter up to $10-30 \mathrm{ml}$ under TAUS guidance in four patients with persistent bleeding. The Foley catheter balloon tamponade was removed 4-6 hours later. The uterus was conserved in all patients, and none of the patients required a recurettage.

Table II: Reproductive outcomes of patients with CSPs treated by suction curettage

\begin{tabular}{|c|c|}
\hline Pregnancy rate & $23 / 25(\% 92)$ \\
\hline Secondary infertility rate & $2 / 25(\% 8)$ \\
\hline Live birth rate & $12 / 23(\% 52,1)$ \\
\hline Missed abortion rate & $6 / 23(\% 26,1)$ \\
\hline Recurrent CSP rate & $3 / 23(\% 13,3)$ \\
\hline $\begin{array}{c}\text { Abnormal placental invasion } \\
\text { rate }\end{array}$ & $2 / 23(\% 8,6)$ \\
\hline Ectopic pregnancy rate & $1 / 23(\% 4,3)$ \\
\hline
\end{tabular}

Table III: Treatment methods used in pregnancies following CSP

\begin{tabular}{|c|c|}
\hline Cesarean Section & $11 / 23(\% 47,8)$ \\
\hline Suction Curettage & $9 / 23(\% 39,1)$ \\
\hline Laparoscopic Salpingectomy & $1 / 23(\% 4,3)$ \\
\hline Hysterotomy & $1 / 23(\% 4,3)$ \\
\hline Cesarean Hysterectomy & $1 / 23(\% 4,3)$ \\
\hline
\end{tabular}

\section{DISCUSSION}

Our study showed that CSP treatment in the early stages of pregnancy by suction curettage alone is a safe and effective method that does not have unfavourable effects on fertility outcomes. This study also revealed that many women prefer to avoid a new pregnancy due to 
the probability of recurrent CSP and uterine ruptures. Meanwhile, in our research, many women $(92 \%, 23 / 25)$ attempted to have children after a previous CSP could conceive. The pregnancies of more than half of the patients who conceived $(52.1 \%, 12 / 23)$ showed a healthy progression and resulted in a live birth.

CSP is a rare iatrogenic complication that occurs at a rate of $0.15 \%$ in women with a history of previous cesarean delivery ${ }^{11}$. Currently; ultrasound constitutes the primary method for diagnosing CSP with a sensitivity of $86.4 \% 12,13$. In the present study, transvaginal ultrasound utilized for diagnostic purposes.

While there are various treatment modalities related to preserving fertility, there is no consensus among gynaecologists on the optimal treatment method for CSP. This is because there are limited studies on the short- and long-term outcomes concerning post-treatment fertility and recurrence rates, due to the low incidence of CSP.

Although there are conflicting data regarding first-line treatment options in CSP management, suction curettage has been reported as the firstline treatment for CSP in many studies ${ }^{2,6}$. However; indeed, the most appropriate approach must be decided based on the patient's clinical condition and the clinician's surgical experience. The surgical approach's advantages include the excision of the trophoblastic mass in a single session, having a lower risk of uterine rupture and bleeding, and having the minimal need for additional treatment 6 . In the study conducted by Sel et al., the success rate of vacuum curettage was reported as $83 \%{ }^{14}$. Petersen et al. showed that performing suction curettage combined with uterine artery embolization has a success rate of $93.6 \% 15$. In another study comparing suction curettage alone and suction curettage plus uterine artery embolization, success rates reported as $90 \%$ and $98 \%$, respectively ${ }^{16}$. We performed suction curettage as the first-line treatment method in our study. We did not reinforce the treatment with uterine artery embolization due to the concern that it could lead to endometrial atrophy in the following period. The success rate of our study was $97 \%$. This high rate may be related to careful patient selection, surgical experience or the surgical technique we applied. Suction curettage is an effective and easily applicable treatment in CSP, but it may be inadequate in some patients, and adjuvant MTX therapy may be required ${ }^{17}$. None of the patients included in our study needed additional treatment in the postoperative period.

The post-treatment pregnancy rate, which was the main focus of the present study, was determined to be higher (92\%) compared with other two previous studies having $82.8 \%^{12}$ and $88 \% 18$ rates, and none of these patients required assisted reproductive technologies (ART).

One of the two studies that have evaluated conception times after CSP treatment reported the mean length of time from scar pregnancy to new pregnancy as 24.6 months ${ }^{19}$, whereas the other reported this interval as 13.3 months and reported that $29 \%$ of their patients achieved pregnancy with in vitro fertilization (IVF) ${ }^{20}$. Compared with these two studies, the meantime to conception in the present study was shorter (mean: 12.3 months) even though ART was not utilized.

There were two patients $(8 \%, 2 / 25)$ with secondary infertility in our study. Despite thorough examination, could not be identified causes for secondary infertility. The secondary infertility rate after CSP was $14.3 \%$ and $12.5 \%$ in two previous studies ${ }^{13,18}$. On the other hand, 19 patients used contraception to avoid 
recurrent CSP and uterine rupture. The most common contraceptive method was combined oral contraceptives.

Spontaneous miscarriage rate is $10-20 \%$ in general populatio ${ }^{21}$. Although this rate was slightly higher than expected in the present study (26\%), it was consistent with previous studies investigating $\mathrm{CSP}^{22}$.

Recurrent CSP (rCSP) was encountered in 3 of our patients (13.3\%). Our result was compatible with two previous study results, including $15.6 \%{ }^{12}$ and $11.1 \%{ }^{13}$.

Patients with a CSP history also demonstrate a higher prevalence of abnormal placental invasion $^{23}$. Early detection of these cases and taking proper precautions are crucial in terms of surgical treatment and referral to tertiary centres $^{24,25}$. There were two patients $(8.6 \%$, $2 / 23$ ) with abnormal placental invasion in our study. One of these patients underwent hysterotomy due to massive acute bleeding in the 17th gestational week, and the other experienced a cesarean hysterectomy in the 36th gestational week due to placenta percreta. These patients can be considered recurrent CSP because previous studies found that CSP and placental invasion abnormalities manifest the same histopathological features ${ }^{26}$. Uterine rupture, massive haemorrhage, hysterectomy, and maternal mortality are the most feared CSP complications ${ }^{10,27}$. The measurement of myometrial thickness between the gestational sac and the bladder is a useful marker in managing the CSP.

Many studies suggested variable cut-off values including $2 \mathrm{~mm}^{28}, 3.5 \mathrm{~mm}^{29}, 4.5 \mathrm{~mm}^{30}$ and suction curettage was not recommended as a good option in patients with myometrial thicknesses below these values due to the risk of uterine rupture and bleeding.

Two recent studies demonstrated that the success rate of ultrasound-guided D\&C (dilation and curettage) in patients with myometrial scar thickness $\geq 3 \mathrm{~mm}$ is $97.6 \%^{31}$ and $97.4 \%^{32}$. Thus, we used a myometrial thickness of $\geq 3 \mathrm{~mm}$ as a cut-off value on ultrasound for suction curettage in our clinic. In this observational study, only one patient (2.3\%) manifested uterine rupture after curettage and 4 (9\%) patients revealed persistent bleeding during the procedure. Although the rate of uterine ruptures was consistent with the literature ${ }^{15}$, the persistent bleeding rate was lower in our study compared with the literature ${ }^{33}$. This lower rate may have resulted from appropriate patient selection, surgical experience or the surgical technique we performed. The adjuvant use of an inflatable Foley balloon catheter to stop or limit haemorrhage in patients with massive bleeding has been reported ${ }^{34}$. In our study, a Foley balloon catheter was used in 4 patients after suction curettage to prevent massive bleeding.

This study's limitations included the lack of comparison of suction curettage with other treatment methods, the possibility of selection bias in the patient records due to the study's single-centre design, and the limited number of patients completing follow-up. It is crucial to know the fertility results after applying this method, which has been preferred as the first treatment option in patients complicated with CSP in recent years. In previous studies, reproductive results of treatment modalities were not evaluated separately, and common reproductive outcomes of different treatment methods were reported $12,13,18$. As far as we know, our study is the first that assessed the reproductive outcomes of patients after suction curettage.

\section{CONCLUSION}

Our results show that TAUS-guided suction curettage is a safe and successful treatment method with minimal adverse effects on future fertility. It is crucial that; If these patients 
conceive, their pregnancy should be monitored by tertiary centres due to the possible risks. Further studies are needed regarding the fertility outcomes in patients with CSP who underwent suction curettage.

Ethics Committee Approval: The local ethics committee of Gaziantep University has approved this study (project number 2019/183).

Declaration of Conflicting Interests: The authors declare that they have no conflict of interest.

Financial Disclosure: No financial support was received.

\section{REFERENCES}

1. Graesslin O, Dedecker F, Quereux C, et al. Conservative treatment of ectopic pregnancy in a cesarean scar Obstetrics \& Gynecology 2005; 105 : 869-71.

2. Wang S, Li Y, Ma X. Lower uterine segment thickness in assessing whether cesarean scar pregnancy patients could be treated with suction curettage. J Matern Fetal Neonatal Med. 2018. https://doi.org/10.1080/14767058.2018. 1531118.

3. Jurkovic D, Hillaby K, Woelfer B, et al. Firsttrimester diagnosis and management of pregnancies implanted into the lower uterine segment cesarean section scar Ultrasound in Obstetrics and Gynecology 2003; 21: 220-7.

4. Maymon R, Halperin R, Mendlovic S. Ectopic pregnancies in a Caesarean scar: a review of the medical approach to an iatrogenic complication. Human Reproduction Update 2004; 10: 515-23.

5. Li N, Zhu F, Fu S, et al. Transvaginal ultrasoundguided embryo aspiration plus local administration of low-dose methotrexate for caesarean scar pregnancy Ultrasound in Medicine \& Biology 2012; 38: 209-13.

6. Polat I, Ekiz A, Acar DK, et al. Suction curettage as first-line treatment in cases with cesarean scar pregnancy: feasibility and effectiveness in early pregnancy The Journal of Maternal-Fetal \& Neonatal Medicine 2016; 29: 1066-71.

7. Sevket O, Keskin S, Ates S, et al. Is methotrexate administration needed for the treatment of caesarean section scar pregnancy in addition to suction curettage? The European Journal of Contraception \& Reproductive Health Care 2014; 19: 128-33.

8. Vial Y, Petignat P, Hohlfeld P. Pregnancy in a cesarean scar Ultrasound in Obstetrics and Gynecology 2000; 16(6): 592-3.

9. Rotas MA, Haberman S, Levgur M. Cesarean scar ectopic pregnancies: etiology, diagnosis, and management Obstetrics \& Gynecology 2006; 107: 1373-81.

10. Mehmet SE, Sezin V, Mehmet O, Talip K, Mehmet ZT Cesarean scar pregnancy: A case report Dicle Medical Journal 2011; 38: 492-4.

11. Ash A, Smith A, Maxwell D. Caesarean scar pregnancy. BJOG. 2007; 114: 253-63.

12. Wang Q, Peng HL, He L, et al. Reproductive outcomes after previous cesarean scar pregnancy: follow up of 189 women Taiwanese Journal of Obstetrics and Gynecology 2015; 54: 551-3.

13. Gao L, Huang Z, Zhang X, et al. Reproductive outcomes following cesarean scar pregnancy-a case series and review of the literature. European Journal of Obstetrics \& Gynecology and Reproductive Biology 2016; 200: 102-7.

14. Sel G, Sucu S, Harma M, Harma MI. Successful management of cesarean scar pregnancy with vacuum extraction under ultrasound guidance. Acute Med Surg. 2018;5: 358-61.

15. Petersen KB, Hoffmann E, Larsen $C R$, et al. Cesarean scar pregnancy: a systematic review of treatment studies Fertility and Sterility 2016; 105 : 958-67.

16. Ou J. Peng P. Li C. Teng L. Liu X. Assessment of the necessity of uterine artery embolization during suction and curettage for caesarean scar pregnancy: a prospective cohort study. BMC Pregnancy Childbirth. 2020; 20: 378. 
17. Fylstra DL. Hysteroscopy and suction evacuation of cesarean scar pregnancies: a case report and review. J. Obstet. Gynae- col. Res. 2014; 40: 853-7.

18. Ben Nagi J, Helmy S, Ofili Yebovi D, et al. Reproductive outcomes of women with a previous history of Caesarean scar ectopic pregnancies Hum Reprod 2007; 22: 2012-5.

19. Shih JC, et al. I Cesarean scar pregnancy: diagnosis with three-dimensional (3D) ultrasound and 3D power Doppler Ultrasound in Obstetrics and Gynecology 2004; 23: 306-7.

20. Tan G, Chong YS, Biswas A. Caesarean scar pregnancy: a diagnosis to consider carefully in patients with risk factors Ann Acad Med Singapore 2005; 34: 216-9.

21. Wood SL, Brain PH. et al. 1 Medical management of missed abortion: a randomized clinical trial. Obstet Gynecol. 2002; 99: 563-6.

22. Seow KM, Hwang JL, Tsai YL, et al. Subsequent pregnancy outcome after conservative treatment of a previous cesarean scar pregnancy Acta Obstetricia et Gynecologica Scandinavica, 2004; 83: 1167-72.

23. Timor Tritsch IE, Monteagudo A, Cali G, et al. Cesarean scar pregnancy and early placenta accreta share common histology Ultrasound in Obstetrics \& Gynecology 2014; 43: 383-95.

24. Buca D, Liberati $M$, Calì $G$, et al. Influence of prenatal diagnosis of abnormally invasive placenta on maternal outcome: systematic review and metaanalysis. Ultrasound Obstet Gynecol 2018; 52: 3049.

25. Morlando M, Buca D, Timor-Tritsch I, et al. Reproductive outcome after cesarean scar pregnancy: a systematic review and meta-analysis. Acta Obstet Gynecol Scand 2020 (May), doi:http://dx.doi.org/10.1111/aogs.13918.

26. Timor Tritsch IE, Monteagudo A, Cali G, et al. Cesarean scar pregnancy is a precursor of morbidly adherent placenta. Ultrasound in Obstetrics \& Gynecology 2014; 44: 346-53.
27. Dior UP, Palma-Dias R, Reidy KL, Cheng C, Healey M. Cesarean scar pregnancies: incidence and factors associated with conversion to surgery from medical management. J Minim Invasive Gynecol. 2018; 19: 31219-6.

28. Tinelli A, Tinelli R, Malvasi A. Laparoscopic management of cervical-isthmic pregnancy: a proposal method Fertility and Sterility 2009; 92: 829.

29. Wang YL, Su TH, Chen HS. Operative laparoscopy for unruptured ectopic pregnancy in a caesarean scar. BJOG: An International Journal of Obstetrics \& Gynaecology 2006; 113: 1035-8.

30. Tekin YB, Ural UM, Balık G, et al. Management of cesarean scar pregnancy with suction curettage: a report of four cases and review of the literature Archives of Gynecology and Obstetrics 2014; 289: 1171-5.

31. Liu S, Sun J, Cai B, et al. Management of cesarean scar pregnancy using ultrasound-guided dilation and curettage. Journal of Minimally Invasive Gynecology 2016; 23: 707-11.

32. Özcan HC, Ugur MG, Balat Ö, et al. Is ultrasoundguided suction curettage a reliable option for treatment of cesarean scar pregnancy? A crosssectional retrospective study. The Journal of Maternal-Fetal \& Neonatal Medicine 2018; 31: 2953-8.

33. Ozdamar 0, Doğer E, Arlıer S, et al. Exogenous cesarean scar pregnancies managed by suction curettage alone or in combination with other therapeutic procedures: A series of 33 cases and analysis of complication profile. J Obstet Gynaecol Research 2016; 42: 927-35.

34. Timor-Tritsch IE, Cali G, Monteagudo A et al. Foley balloon catheter to prevent or manage bleeding during treatment for cervical and Cesarean scar pregnancy. Ultrasound Obstet. Gynecol. 2015; 46: 118-23. 